\title{
LARGE-SCALE CANDIDATE GENE STUDY OF LEPROSY SUSCEPTIBILITY IN THE KARONGA DISTRICT OF NORTHERN MALAWI
}

\author{
JODENE FITNESS, SIAN FLOYD, DAVID K. WARNDORFF, LIFTED SICHALI, LORREN MWAUNGULU, \\ AMELIA C. CRAMPIN, PAUL E. M. FINE, AND ADRIAN V. S. HILL \\ Wellcome Trust Centre for Human Genetics, University of Oxford, Oxford, United Kingdom; Department of Tropical Hygiene, \\ London School of Hygiene and Tropical Medicine, London, United Kingdom; Karonga Prevention Study, \\ Chilumba, Karonga District, Malawi
}

\begin{abstract}
We present a large case-control candidate gene study of leprosy susceptibility. Thirty-eight polymorphic sites from 13 genes were investigated for their role in susceptibility to leprosy by comparing 270 cases with 452 controls in Karonga district, northern Malawi. Homozygotes for a silent $\mathrm{T} \rightarrow \mathrm{C}$ change in codon 352 of the vitamin $\mathrm{D}$ receptor gene appeared to be at high risk (odds ratio $[\mathrm{OR}]=4.3,95 \%$ confidence interval $[\mathrm{CI}]=1.6-11.4, P=0.004$ ), while homozygotes for the McCoy b blood group defining variant K1590E in exon 29 of the complement receptor 1 (formerly $\mathrm{CD} 35)$ gene appeared to be protected $(\mathrm{OR}=0.3,95 \% \mathrm{CI}=0.1-0.8, P=0.02)$. Borderline evidence for association with leprosy susceptibility was found for seven polymorphic sites in an additional six genes. Some of these apparent associations may be false-positive results from multiple comparisons, and several associations suggested by studies in other populations were not replicated here. These data provide evidence of inter-population heterogeneity in leprosy susceptibility.
\end{abstract}

\section{INTRODUCTION}

Leprosy is a chronic disabling disease attributable to infection with Mycobacterium leprae. It has a broad clinical spectrum: at one pole is paucibacillary (PB) leprosy, characterized by a low bacterial count, strong cell-mediated immunity, and localized disease. At the other pole, multibacillary (MB) leprosy is characterized by a high bacterial count, poor cellmediated immunity and strong humoral immunity, with progressive and disseminated disease. The natural history of leprosy is poorly understood, but family studies, segregation analyses, and twin studies provide evidence that, in addition to environmental and exposure factors, host genetic factors influence leprosy susceptibility. ${ }^{1-4}$

Elucidation of genetic determinants of host susceptibility to leprosy could facilitate the development of better preventative and therapeutic strategies. The earliest strong evidence pointed towards the major histocompatibility complex region on chromosome $6 .{ }^{5,6}$ More recently susceptibility loci have been mapped using linkage analysis of multi-case families to chromosomes 10p13 and 20p12 in populations in south India and to chromosome 6q25 and, again, 10p13, in Vietnam., ${ }^{4,7,8}$ The linkage on chromosome 10p13 appears to be mainly with tuberculoid leprosy and the chromosome 6q25 linkage with leprosy per se. Association studies in various populations have indicated that several other non-HLA genes may also influence either leprosy susceptibility or the type of leprosy that develops upon infection. ${ }^{3}$ In general, these association studies have been carried out on relatively small sample sizes, and some of the reported associations may represent chance findings, particularly in studies that examined numerous variants of multiple genes. A major objective of the present study was to re-evaluate reported associations in an independent population.

The Karonga Prevention Study (KPS), a long-term epidemiologic study of mycobacterial disease in the Karonga District of northern Malawi, provides an excellent opportunity to attempt to replicate previously reported leprosy associations as well as to investigate de novo hypotheses. A case-control association study was thus designed to investigate a large number of putative susceptibility genes (38 polymorphisms from 13 genes) in this population. The genotyping was performed blind to the disease status of the samples.

Polymorphisms in tumor necrosis factor (TNF, formerly $\mathrm{TNF} \alpha$ ), the vitamin $\mathrm{D}$ receptor (VDR), toll-like receptor 2 (TLR2), and lymphotoxin alpha (LTA, formerly TNF $\beta$ ) are associated with leprosy in other populations and were included here in an attempt to replicate these findings. ${ }^{3}$ An interleukin-10 (IL10) promoter that has recently been suggested to be associated with leprosy susceptibility in Brazil, and other polymorphisms that may influence expression of the immunomodulatory genes IL10 and TLR2 were included (Segal S and others, unpublished data). ${ }^{9}$ Polymorphisms in the genes encoding solute carrier family 11 , member 1 (SLC11A1, formerly NRAMP1), mannose-binding lectin (MBL2, formerly MBP or MBL) and interferon- $\gamma$ (IFNG) were investigated because they have been reported to be associated, in at least one population, with susceptibility to a related mycobacterial disease, tuberculosis. ${ }^{10}$ The toll-like receptor 4 (TLR4), IL10, and intercellular adhesion molecule 1 (ICAM-1, formerly CD54) loci contain polymorphisms that are associated with susceptibility to other infectious diseases, and it was speculated that these genes might represent general infectious disease susceptibility loci. ${ }^{11-13}$ The caspase recruitment domain family, member 15 (CARD15, formerly NOD2) and CR1 were selected as functional candidates because of their roles in innate immunity and potential role in mycobacterial disease. The chemokine (C-C motif) ligand 3 (CCL3, formerly MIP1 $\alpha$ ) was selected as a functional candidate due to its involvement in T helper cell 1 (TH1) differentiation.

\section{METHODS}

The study protocol was approved by the National Health Sciences Research Committee of Malawi and by the Ethics Committee of the London School of Hygiene and Tropical Medicine.

Recruitment and sample collection. Cases were ascertained within the context of the KPS, a long-term epidemiologic study of mycobacterial disease in the Karonga District, a rural area of northern Malawi. The population and basic 
field methods of the KPS have been described in detail elsewhere. ${ }^{14,15}$ Leprosy cases were identified in the context of total population surveys during the 1980s, and through "enhanced" passive detection (examination of all individuals who appeared at health centers) in the 1990s, in addition to selfreporting. Individuals were examined first by paramedical leprosy control assistants (LCAs), and suspects referred to project Medical Officers for review examination and (4-mm punch) biopsy. Diagnostic certainty was defined in terms of clinical, skin slit smear, and histopathologic data. ${ }^{16}$ Cases were defined as $\mathrm{PB}$ or MB based upon an algorithm that took into account all clinical, bacteriologic (slit skin smear), biopsy, and historical record information. The algorithm implies a conservative definition of MB (e.g., biopsy or slit skin smear bacterial index $>1$ ).

Recruitment for this study began in 1996. Since leprosy incidence had decreased dramatically in the district, cases were selected retrospectively from project data files. Only cases that met strict diagnostic criteria were included ( $\mathrm{N}$ and $\mathrm{M}$ categories as stipulated elsewhere $\left.{ }^{16}\right)$. Individuals were eligible for selection as controls if they were resident in the district during the 1986-1989 population survey, and had no history of either tuberculosis or leprosy. Controls were matched to cases by age $(15-19,20-24,25-29,30-34,35-44$, 45-54, 55-64, and > 65 years old), sex, and geographic area (residence within $1 \mathrm{~km}$ of the case). First- or second-degree relatives of cases were not eligible for selection as controls. Each case was matched to up to three controls.

Cases and controls were visited in their homes by field teams consisting of an LCA and an interviewer. After having the study explained to them, those who consented were examined and invited to provide a blood or saliva sample for genetic testing (those who were willing to provide blood were told their blood group, and offered syphilis tests with treatment and also human immunodeficiency virus [HIV] counseling and testing if they so desired). All cases ascertained since 1987 have been offered voluntary counseling and HIV testing at the time of initial registration as part of a continuous case control study of leprosy, tuberculosis, and HIV. ${ }^{17}$ Blood $(7.5 \mathrm{~mL})$ was collected into EDTA and placed in vaccine carriers with wet ice until it reached the project laboratory within three days of collection, where cells were separated and stored at $-70^{\circ} \mathrm{C}$. The DNA was separated using Nucleon kits (Scotlab, Coatbridge, United Kingdom) following the manufacturer's instructions, and shipped at $4{ }^{\circ} \mathrm{C}$ to the Wellcome Trust Center for Human Genetics in Oxford, United Kingdom for analysis.

Genotyping. Genotyping was performed blind to disease status. A variety of genotyping methods were used to investigate 38 polymorphisms from 13 candidate genes (Tables 1 and 2). Four CARD15 polymorphisms were genotyped using polymerase chain reaction-restriction fragment length polymorphism (PCR-RFLP), the IFN- $\gamma+874$ single nucleotide polymorphism (SNP) was typed using amplification refractory mutation system PCR, and the CARD15 and IFNG products were analyzed using agarose gel electrophoresis. ${ }^{18,19}$ Seven polymorphisms in SLC11A1, LTA, CCL3, and TLR2 were genotyped by fluorescence PCR followed by electrophoresis and detection using an ABI fluorescent DNA sequencer (Applied Biosystems, Foster City, CA) as de-

TABLE 1

Oligonucleotides and conditions used for non-LDR genotyping*

\begin{tabular}{|c|c|c|c|c|}
\hline Gene & $\begin{array}{l}\text { Location, polymorphism } \\
\text { Amino acid change } \\
\text { (Restriction enzyme) }\end{array}$ & $\begin{array}{l}\text { Genotyping method } \\
\text { (\% agarose gel) }\end{array}$ & PCR primers & $\begin{array}{l}\text { PCR temperature } \\
\text { product length }\end{array}$ \\
\hline \multirow{8}{*}{$\begin{array}{l}\text { CARD15 } \\
\text { (NOD2) }\end{array}$} & Exon $4,802 \mathrm{C} \rightarrow \mathrm{T}$ & PCR-RFLP & F: CAGTCTCGCTTCCTCAGTACC & $55^{\circ} \mathrm{C}$ \\
\hline & P268S (Bam HI) & $(3 \%)$ & R: AGTGTCCGCATCGTCATTG & $187 \mathrm{bp}$ \\
\hline & Exon $4,2104 \mathrm{C} \rightarrow \mathrm{T}$ & PCR-RFLP & F: TTCCTGGCAGGGCTGTTGTCCtGG & $55^{\circ} \mathrm{C}$ \\
\hline & $\mathrm{R} 702 \mathrm{~W}$ ( $M s p \mathrm{I})$ & $(3 \%)$ & R: GGATGGAGTGGAAGTGCTTG & $139 \mathrm{bp}$ \\
\hline & Exon $8,2722 \mathrm{G} \rightarrow \mathrm{C}$ & PCR-RFLP & F: AGGCCACTCTGGGATTGAG & $55^{\circ} \mathrm{C}$ \\
\hline & G908R (Hha I) & $(3 \%)$ & R: GTGATCACCCAAGGCTTCAG & 196 bp \\
\hline & Exon 11, 3020insC & PCR-RFLP & $\mathrm{F}:$ GGCAGAAGCCCTCCTGCAGGgCC & $55^{\circ} \mathrm{C}$ \\
\hline & $1007 \mathrm{fs}(A p a \mathrm{I})$ & $(4 \%)$ & R: CCTCAAAATTCTGCCATTCC & $152 \mathrm{bp}$ \\
\hline \multirow{7}{*}{$\begin{array}{l}\text { CCL3 } \\
\text { (MIP1- } \alpha) \\
\text { IFNG }\end{array}$} & Promoter, microsatellite & Fluorescence PCR & F: FAM-AAGGCATGTATTTCCAAGC & $58^{\circ} \mathrm{C}$ \\
\hline & $(\mathrm{TA})_{\mathrm{n}}$ at -906 & & R: CTGACCCAGCATCGTTTA & 327-337 bp \\
\hline & Intron 1 & ARMS PCR & IFNGT: TTCTTACAACACAAAATCAAATCT & $62^{\circ} \mathrm{C}, 50^{\circ} \mathrm{C}$ \\
\hline & $874 \mathrm{~T} \rightarrow \mathrm{A}$ & $(2 \%)$ & IFNGA: TTCTTACAACACAAAATCAAATCA & $461 \mathrm{bp}$ \\
\hline & & & IFNGCOM: TCAACAAAGCTGATACTCCA & \\
\hline & & & HGHF : GCCTTCCCAACCATTCCCTTA & \\
\hline & & & HGHR: TCACGGATTTCTGTTGTGTTTC & $426 \mathrm{bp}$ \\
\hline \multirow{2}{*}{$\begin{array}{l}\text { LTA } \\
\qquad(\text { TNF- } \beta)\end{array}$} & 5'UTR, microsatellite & Fluorescence PCR & $\mathrm{F}:$ GCCTCTAGATTTCATCCAGCCACAG & $58^{\circ} \mathrm{C}, 50^{\circ} \mathrm{C}$ \\
\hline & $(\mathrm{AC} / \mathrm{GT})_{\mathrm{n}}$ at $-3.5 \mathrm{~kb}$ & & R: HEX-ССТСТСТССССТGCAACACACA & 93-119 bp \\
\hline \multirow{8}{*}{$\begin{array}{l}\text { SLC11A1 } \\
\text { (NRAMP1) }\end{array}$} & Promoter, microsatellite & Fluorescence PCR & F: FAM-TTCTGTGCCTCCCAAGTTAGC & $52^{\circ} \mathrm{C}$ \\
\hline & $(\mathrm{GT}) \mathrm{n}$ & & R: ACTCGCATTAGGCCAACGAG & $180-220 \mathrm{bp}$ \\
\hline & Exon 2, & Fluorescence PCR & F: GTGACAAGGGTCCCCAA & $60^{\circ} \mathrm{C}$ \\
\hline & 9 bp del & & R: TET-CGGTTTTGTGTCTGGGAT & 143,132 bp \\
\hline & 3' UTR, & Fluorescence PCR & F: GCATCTCCCCAATTCATGGT & $60^{\circ} \mathrm{C}$ \\
\hline & TGTG ins/del & & R: TET-AACTGTCCCACTCTATCCTG & 240,244 bp \\
\hline & 3' UTR & Fluorescence PCR & F: TET-CCTAGCGCAGCCATGTGATTACCC & $58^{\circ} \mathrm{C}$ \\
\hline & CAAA ins/del & & R: AGCCTGTGTCCCGCCCAAGTCCT & 234,238 bp \\
\hline \multirow[t]{2}{*}{ TLR2 } & Intron 2 & Fluorescence PCR & F: TATCCCCATTCATTCGTTCCATT & $58^{\circ} \mathrm{C}$ \\
\hline & microsatellite & & $R:$ FAM-ACCCCCAAGACCCACACC & 213-243 bp \\
\hline
\end{tabular}

$*$ LDR $=$ ligation detection reaction; PCR $=$ polymerase chain reaction; CARD15 = caspase recruitment family, member $15 ;$ RFLP $=$ restriction fragment length polymorphism; bp = basepairs; CCL3 = chemokine (C-C motif) ligand 3: IFNG $=$ interferon- $\gamma$; ARMS $=$ amplification refractory mutation system; LTA $=$ lymphotoxin $\alpha$; UTR $=$ untranslated region; TNF- $\beta$ $=$ tumor necrosis factor $\beta$; SLC11A1 = solute carrier family 11 , member 1 ; del = deletion; ins = insertion; TLR2 = toll-like receptor 2 ; fs = frameshift. 


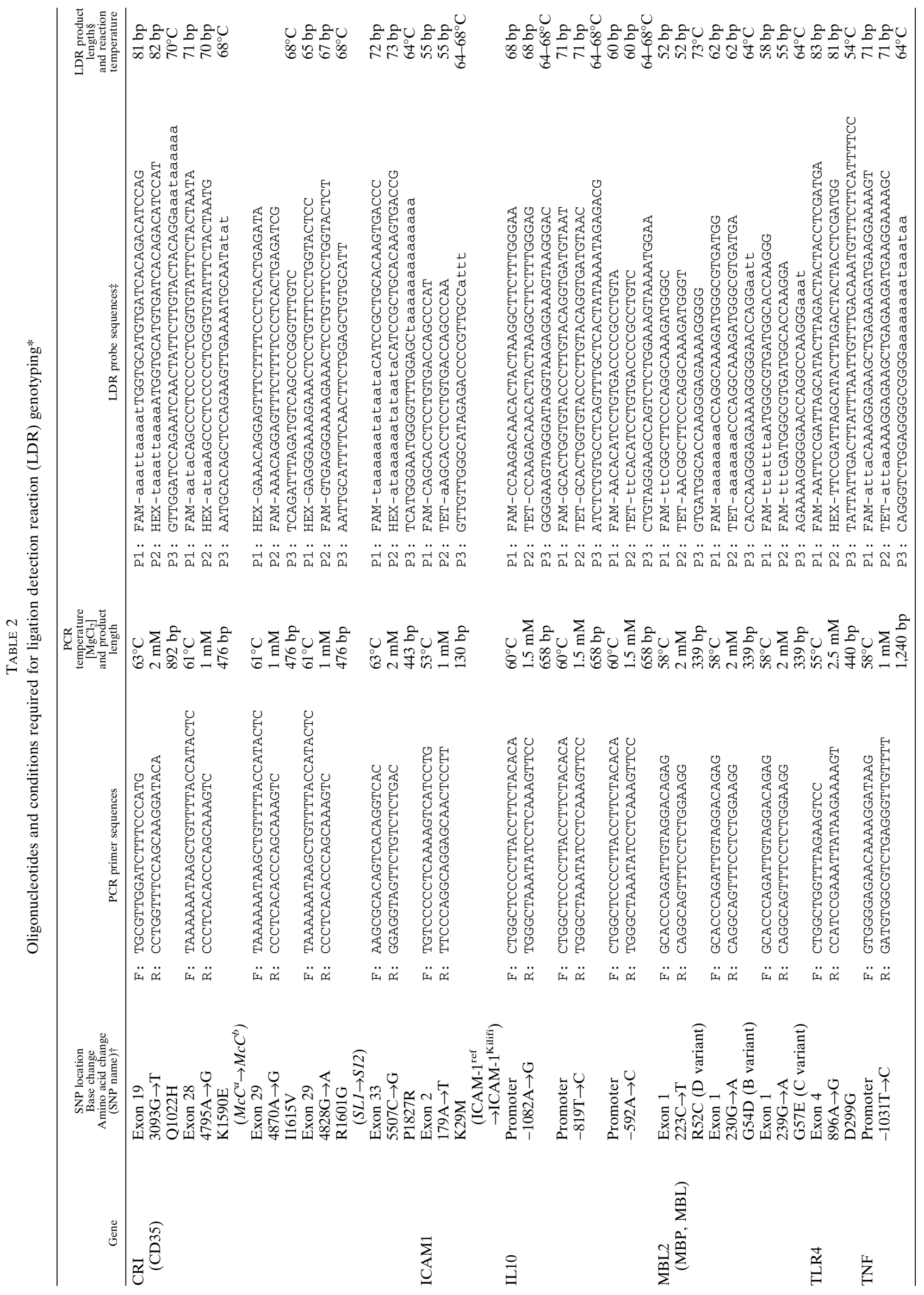




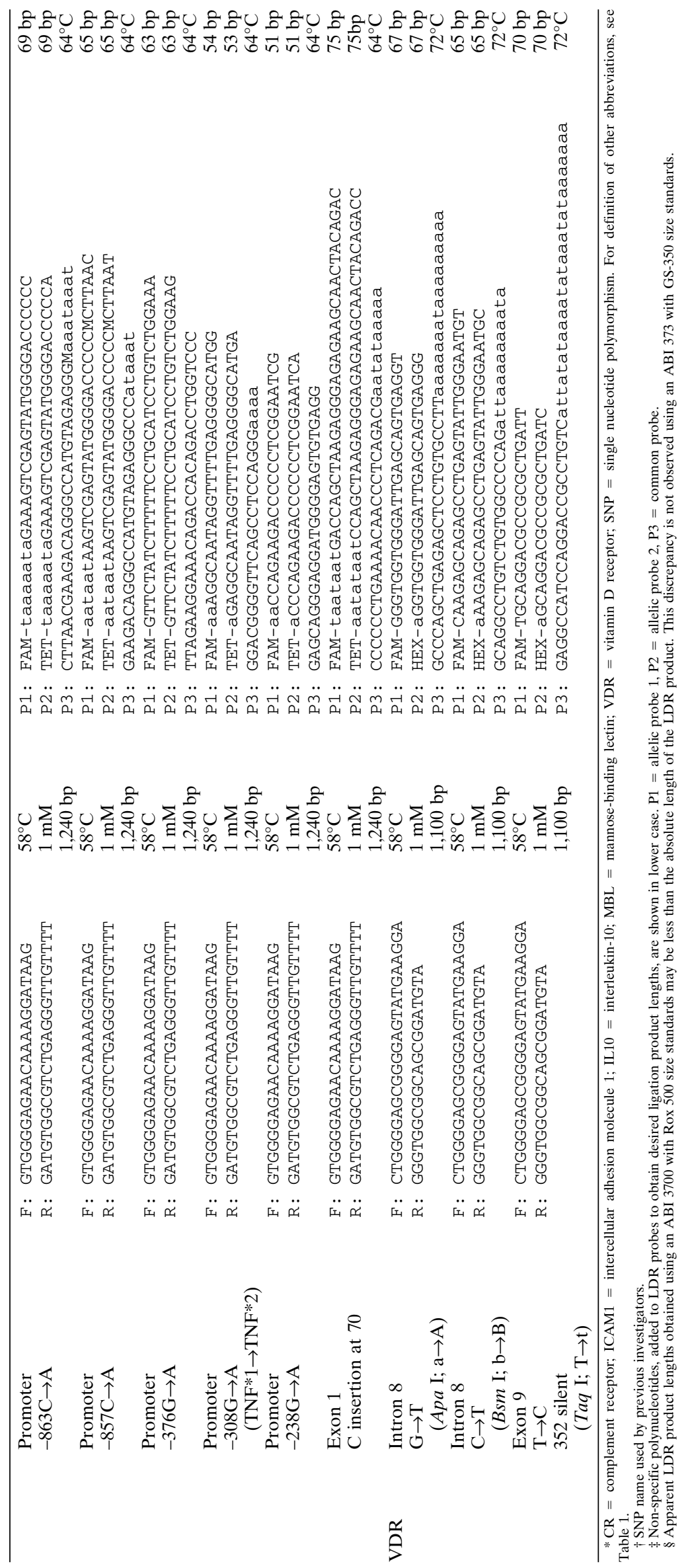


scribed later in this report (Segal S and others, unpublished data). ${ }^{20,21}$ The PCR primers, conditions, and restriction enzymes used are shown in Table 1.

Direct sequence analysis. Direct sequence analysis was used to determine whether the TLR2 R677W, R753Q, and CARD15 R790Q variants were present in the Malawi population $^{13,22}$ (National Center for Biotechnology Information SNP database, Bethesda, MD). The PCR primers and thermocycles were TLR2 exon 3 586-basepair (bp) segment: 5'gcgtggccagcaggttcag- $3^{\prime}, 5^{\prime}$-gggccactccaggtaggtcttg-3' (thermocycles: one cycle at $94^{\circ} \mathrm{C}$ for four minutes; 36 cycles at $94^{\circ} \mathrm{C}$ for 30 seconds, $58^{\circ} \mathrm{C}$ for 40 seconds, and $72^{\circ} \mathrm{C}$ for $60 \mathrm{sec}-$ onds; and one cycle at $72^{\circ} \mathrm{C}$ for two minutes) and CARD15 exon 4 509-bp segment: 5'-gccgagccgcacaacctt-3', 5'-gtgctcccccatacctgaaca-3' (thermocycles: one cycle at $94^{\circ} \mathrm{C}$ for five minutes; 35 cycles at $60^{\circ} \mathrm{C}$ for 30 seconds, and $72^{\circ} \mathrm{C}$ for 45 seconds; and one cycle at $72^{\circ} \mathrm{C}$ for four minutes). The PCR (2 $\times 25 \mu \mathrm{L})$ and sequencing $(20 \mu \mathrm{L})$ reaction were performed using standard conditions. Sequence analysis was performed using an ABI 3700 fluorescent DNA sequencer. Each segment was sequenced in both directions.

Genotyping using the post-PCR multiplexed ligation detection reaction (LDR). The LDR was used to genotype the remaining 23 SNPs located in seven genes. ${ }^{23}$ Briefly, fragments containing the SNPs of interest were PCR-amplified using appropriate primers and conditions (Table 2). Amplifications were performed in a total volume of $15 \mu \mathrm{L}$ and contained $10 \mathrm{mM}$ Tris- $\mathrm{HCl}, \mathrm{pH} 8.3,50 \mathrm{mM} \mathrm{KCl}, 1-2.5 \mathrm{mM}$ $\mathrm{MgCl}_{2}, 200 \mu \mathrm{M}$ of each dNTP, $0.2 \mu \mathrm{M}$ of each primer, approximately $50 \mathrm{ng}$ of DNA, and 0.5 units of Amplitaq Gold polymerase (Perkin-Elmer, Boston, MA). To prevent polymerase extension during the subsequent LDR procedure, residual polymerase activity was removed by incubation with $1: 10$ volume of $1 \mathrm{mg} / \mathrm{mL}$ of proteinase $\mathrm{K}$ in $50 \mathrm{mM}$ EDTA at $37^{\circ} \mathrm{C}$ for 30 minutes and $55^{\circ} \mathrm{C}$ for 10 minutes. The proteinase $\mathrm{K}$ was inactivated by incubation at $99^{\circ} \mathrm{C}$ for 10 minutes.

A set of three probes consisting of two fluorescently labeled allelic and one common probe was designed for each of the SNPs investigated using the LDR (Table 2). The common probes (100 pmol of each) were $5^{\prime}$ phosphorylated in a volume of $100 \mu \mathrm{L}$ using 10 units of T4 polynucleotide kinase and $1 \mathrm{mM}$ ATP in $70 \mathrm{mM}$ Tris- $\mathrm{HCl}$ buffer, $\mathrm{pH}$ 7.6, containing 10 $\mathrm{mM} \mathrm{MgCl}{ }_{2}$ and $5 \mathrm{mM}$ dithiothreitol. After incubation at $37^{\circ} \mathrm{C}$ for 45 minutes, the $\mathrm{T} 4$ kinase was inactivated by the addition of $20 \mu \mathrm{g}$ of proteinase $\mathrm{K}$ in $100 \mu \mathrm{L}$ of TE buffer $(10 \mathrm{mM}$ Tris-HCl, $5 \mathrm{mM}$ EDTA, $\mathrm{pH} 8.0$ ) and incubating at $37^{\circ} \mathrm{C}$ for 30 minutes. The proteinase $\mathrm{K}$ was inactivated by incubation at $99^{\circ} \mathrm{C}$ for 10 minutes.

The multiplexed LDR was performed in $15-\mu \mathrm{L}$ volumes of $20 \mathrm{mM}$ Tris- $\mathrm{HCl}$ buffer, $\mathrm{pH}$ 7.6, containing $25 \mathrm{mM} \mathrm{KCl}, 10$ $\mathrm{mM} \mathrm{MgCl} 2,1 \mathrm{mM} \mathrm{NAD}{ }^{+}, 10 \mathrm{mM}$ dithiothreitol, $0.1 \%$ Triton $\mathrm{X}-100,10 \mathrm{nM}(200 \mathrm{fmol})$ of each LDR probe, $2 \mu \mathrm{L}$ of PCR product, and 2 units of Taq DNA ligase. The reactions were prepared on ice and then initiated by placing on PCR blocks pre-heated to $95^{\circ} \mathrm{C}$. An initial one-minute denaturation at $95^{\circ} \mathrm{C}$ was followed by 15 thermal cycles of denaturation at $95^{\circ} \mathrm{C}$ for 15 seconds, and annealing and ligation at the appropriate temperature (Table 2) for four minutes. The activity of the ligase was stopped after 15 cycles by cooling to $4^{\circ} \mathrm{C}$ and adding $2 \mu \mathrm{L}$ of $100 \mathrm{mM}$ EDTA.

Electrophoresis and detection of multiplexed and/or pooled LDR or fluorescent PCR products was performed on an $\mathrm{ABI} 373$ or $\mathrm{ABI} 3700$ fluorescent DNA sequencer. For the $\mathrm{ABI} 3700,1 \mu \mathrm{L}$ of LDR product was added to $10 \mu \mathrm{L}$ of Hi-Di formamide and $0.01 \mu \mathrm{L}$ of $8 \mathrm{nM}$ ABI Genescan-500 Rox size standards (Applied Biosystems). For the ABI373, $2 \mu \mathrm{L}$ of LDR product was added to $1.5 \mu \mathrm{L}$ of 5:1 deionized formamide, $25 \mathrm{mM}$ EDTA with blue dextran $(1 \mathrm{mg} / \mathrm{mL})$, and $0.5 \mu \mathrm{L}$ of fluorescently labeled size standards (GeneScan-350 tetramethylrhodamine [TAMRA]). After denaturation, the product was subjected to electrophoresis on $6 \%$ polyacrylamide gels. Product sizes were calculated relative to the standard with Genescan 3.5 (Perkin Elmer Applied Biosystems, Warrington, United Kingdom) using the second order least squares method. Automated allele calling of LDR products was performed using Genotyper 2.5 (Perkin Elmer Applied Biosystems).

Statistical analysis. For each polymorphism, the percentage of individuals with a particular genotype was calculated separately for cases and controls. Conditional logistic regression was used to quantify the association between disease and genotype, with and without controlling for ethnic group, and with and without restriction to PB cases. The percentage of cases with a particular genotype was also calculated separately for $\mathrm{PB}$ and $\mathrm{MB}$ cases.

\section{RESULTS}

Recruitment. A total of 334 cases and 702 controls were selected from the database and sought in the field. Of the 334 cases, 22 had left the district and 34 had died by the time they were sought for genetics testing, 7 were alive but neither a blood nor a buccal swab specimen were provided, and for one case data were not available for a matched control. This gave a total of 270 cases that could be included in analyses, 26 of which were MB. Of the 702 controls that were sought, 74 had left the district and 90 had died by the time they were sought for genetics testing, 26 were alive but neither a blood nor a buccal swab specimen were provided, and for 60 data on the matched case were not available. Thus, 452 controls were included in these analyses. There were one or two controls for each case. Blood specimens were available for all except eight individuals, who provided buccal swabs.

Direct sequence analysis. Sequence analysis of 83 individuals (including cases and controls) indicated that the TLR2 R677W and R753Q variants were not present, or were very rare, in northern Malawi. Likewise, the CARD15 SNP R790Q was not found upon sequencing of 63 individuals. Accordingly, further genotyping of these SNPs was not performed.

Genotyping results. The PCR-RFLP analysis of more than 150 Malawians indicated that the CARD15 variants P268S, R702W, G908R, and 1007fs were not present in this population. The TNF-1031 variant was also not found. The MBL2 R52C, MBL2 G54D, TNF + 70, and -857 variants were very rare in Karonga District, occurring with an allele frequency of $<1.0 \%$. No homozygotes of these variants were identified.

Association study results for leprosy susceptibility. The genotype frequencies and odds ratios (ORs) of the 26 variants that were sufficiently polymorphic for leprosy association analysis are shown in Table 3, with ORs controlled for ethnic group. The results shown combine $\mathrm{PB}$ and $\mathrm{MB}$ cases, but all results were unchanged when restricted to PB cases. For most polymorphisms, there was no evidence of an association with 
TABLE 3

Genotype frequencies for all leprosy (paucibacillary and multibacillary)* cases and controls, and odds ratios (ORS) controlled for age, sex, area of residence, and ethnic group $\dagger$

\begin{tabular}{|c|c|c|c|c|c|c|c|}
\hline \multirow[b]{2}{*}{ Gene } & \multirow[b]{2}{*}{ Polymorphism } & \multirow[b]{2}{*}{ Genotype } & \multicolumn{2}{|c|}{ Case } & \multicolumn{2}{|c|}{ Control } & \multirow[b]{2}{*}{ (95\% confidence interval) } \\
\hline & & & $\%$ & $\mathrm{n}$ & $\%$ & $\overline{\mathrm{n}}$ & \\
\hline \multirow{5}{*}{$\begin{array}{l}\text { CCL3 } \\
\text { (MIP1- } \alpha)\end{array}$} & Promoter microsatellite & $331 / 331$ & 41 & 54 & 46 & 131 & \\
\hline & $(\mathrm{TA})_{\mathrm{n}}$ at -906 & $331 / 327$ & 31 & 40 & 25 & 71 & $1.4(0.7-2.7), P=0.37$ \\
\hline & & $331 / 333$ & 16 & 21 & 18 & 52 & $0.9(0.4-2.0), P=0.79$ \\
\hline & & Other & 12 & 16 & 11 & 31 & $1.0(0.4-2.9), P=0.94$ \\
\hline & & & & 131 & & 285 & $(110,146) \ddagger$ \\
\hline \multirow[t]{20}{*}{ CR1 } & Exon 19 & $\mathrm{~g} / \mathrm{g}$ & 79 & 131 & 81 & 151 & \\
\hline & $3093 \mathrm{G} \rightarrow \mathrm{T}$ & $\mathrm{g} / \mathrm{t}$ & 20 & 33 & 17 & 31 & $1.1(0.5-2.1), P=0.86$ \\
\hline & Q1022H & $t / t$ & 1 & 2 & 2 & 4 & $0.4(0.06-2.6), P=0.33$ \\
\hline & & & & 166 & & 186 & $(136,136)$ \\
\hline & Exon 28 & $\mathrm{a} / \mathrm{a}$ & 65 & 164 & 60 & 238 & \\
\hline & $4795 \mathrm{~A} \rightarrow \mathrm{G}$ & $\mathrm{a} / \mathrm{g}$ & 32 & 80 & 34 & 135 & $0.8(0.5-1.1), P=0.18$ \\
\hline & K1590E & $\mathrm{g} / \mathrm{g}$ & 3 & 7 & 6 & 26 & $0.3(0.1-0.8), P=0.02$ \\
\hline & $\left(M c C^{a} \rightarrow M c C^{b}\right)$ & & & 251 & & 399 & $(245,374)$ \\
\hline & Exon 29 & $\mathrm{~g} / \mathrm{g}$ & 45 & 114 & 49 & 196 & \\
\hline & $4828 \mathrm{G} \rightarrow \mathrm{A}$ & $\mathrm{g} / \mathrm{a}$ & 45 & 114 & 40 & 157 & $1.3(0.9-1.9), P=0.12$ \\
\hline & R1601G & $\mathrm{a} / \mathrm{a}$ & 10 & 24 & 11 & 42 & $1.0(0.5-1.9), P=0.99$ \\
\hline & $(S l l \rightarrow S l 2)$ & & & 252 & & 395 & $(246,371)$ \\
\hline & Exon 29 & $\mathrm{~g} / \mathrm{g}$ & 76 & 192 & 79 & 311 & \\
\hline & $4870 \mathrm{~A} \rightarrow \mathrm{G}$ & $\mathrm{g} / \mathrm{a}$ & 23 & 57 & 20.5 & 81 & $1.3(0.9-2.0), P=0.21$ \\
\hline & $\mathrm{I} 1615 \mathrm{~V}$ & $\mathrm{a} / \mathrm{a}$ & 1 & 3 & 0.5 & 2 & $1.7(0.3-11.1), P=0.58$ \\
\hline & & & & 252 & & 394 & $(246,370)$ \\
\hline & Exon 33 & $\mathrm{c} / \mathrm{c}$ & 71 & 128 & 79 & 172 & \\
\hline & $5507 \mathrm{C} \rightarrow \mathrm{G}$ & $\mathrm{c} / \mathrm{g}$ & 28 & 51 & 18 & 40 & $1.4(0.8-2.5), P=0.21$ \\
\hline & P1827R & $\mathrm{g} / \mathrm{g}$ & 1 & 2 & 3 & 7 & $0.2(0.01-1.7), P=0.12$ \\
\hline & & & & 181 & & 219 & $(153,168)$ \\
\hline \multirow[t]{4}{*}{ ICAM1 } & Exon 2 & $\mathrm{a} / \mathrm{a}$ & 54 & 112 & 55 & 134 & \\
\hline & $179 \mathrm{~A} \rightarrow \mathrm{T}$ & $\mathrm{a} / \mathrm{t}$ & 32 & 68 & 31 & 76 & $1.1(0.6-1.7), P=0.83$ \\
\hline & Af & $t / t$ & 14 & 29 & 14 & 35 & $1.0(0.5-2.0), P=0.93$ \\
\hline & $\left(\right.$ ICAM- $1^{\text {ref }} \rightarrow$ ICAM- $\left.1^{\text {Kilifi }}\right)$ & & & 209 & & 245 & $(189,208)$ \\
\hline \multirow[t]{4}{*}{ IFNG } & Intron 1 & $\mathrm{a} / \mathrm{a}$ & 67 & 157 & 66 & 265 & \\
\hline & $874 \mathrm{~T} \rightarrow \mathrm{A}$ & $\mathrm{a} / \mathrm{t}$ & 28 & 67 & 27 & 109 & $1.1(0.7-1.6), P=0.72$ \\
\hline & & $t / t$ & 5 & 12 & 7 & 28 & $0.8(0.4-1.8), P=0.59$ \\
\hline & & & & 236 & & 402 & \\
\hline \multirow{12}{*}{ IL10 } & Promoter & $\mathrm{c} / \mathrm{c}$ & 46 & 97 & 43 & 157 & \\
\hline & $-592 \mathrm{C} \rightarrow \mathrm{A}$ & c/a & 38 & 81 & 47 & 169 & $0.7(0.5-1.1), P=0.13$ \\
\hline & & $\mathrm{a} / \mathrm{a}$ & 16 & 34 & 10 & 36 & $1.7(1.0-3.3), P=0.06$ \\
\hline & & & & 212 & & 362 & $(203,296)$ \\
\hline & Promoter & $\mathrm{c} / \mathrm{c}$ & 44 & 95 & 42 & 147 & \\
\hline & $-819 \mathrm{C} \rightarrow \mathrm{T}$ & $\mathrm{c} / \mathrm{t}$ & 41 & 88 & 48 & 170 & $0.8(0.5-1.2), P=0.23$ \\
\hline & & $t / t$ & 15 & 32 & 10 & 36 & $1.6(0.9-3.0), P=0.11$ \\
\hline & & & & 215 & & 353 & $(204,293)$ \\
\hline & Promoter & $\mathrm{a} / \mathrm{a}$ & 45 & 86 & 43 & 149 & \\
\hline & $-1082 \mathrm{~A} \rightarrow \mathrm{G}$ & $\mathrm{a} / \mathrm{g}$ & 44 & 84 & 44 & 154 & $1.0(0.6-1.5), P=0.96$ \\
\hline & & $\mathrm{g} / \mathrm{g}$ & 11 & 21 & 13 & 46 & $0.7(0.4-1.4), P=0.30$ \\
\hline & & & & 191 & & 349 & $(183,262)$ \\
\hline \multirow{15}{*}{$\begin{array}{l}\text { LTA } \\
\text { (TNF- } \beta \text { ) }\end{array}$} & $5^{\prime}$ UTR microsatellite & 101 absent & 89 & 164 & 89 & 296 & \\
\hline & $(\mathrm{AC} / \mathrm{GT})_{\mathrm{n}}$ at $-3.5 \mathrm{~kb} \S$ & 1011 copy & 10 & 18 & 11 & 36 & $0.9(0.5-1.7), P=0.80$ \\
\hline & & 1012 copies & 1 & 2 & 0.3 & 1 & \\
\hline & & & & $\begin{array}{r}184 \\
06\end{array}$ & & $\begin{array}{l}333 \\
196\end{array}$ & \\
\hline & & $\begin{array}{l}103 \text { absent } \\
1031 \text { copy }\end{array}$ & $\begin{array}{l}52 \\
45\end{array}$ & $\begin{array}{l}96 \\
83\end{array}$ & $\begin{array}{l}59 \\
36\end{array}$ & $\begin{array}{l}190 \\
121\end{array}$ & $1.2(0.8-1.8), P=0.42$ \\
\hline & & 1032 copies & 3 & 5 & 5 & 16 & \\
\hline & & & & 184 & & 333 & \\
\hline & & 105 absent & 49 & 90 & 58 & 192 & \\
\hline & & 1051 copy & 42 & 78 & 37 & 124 & $1.6(1.1-2.4), P=0.03$ \\
\hline & & 1052 copies & 9 & 16 & 5 & 17 & \\
\hline & & & & 184 & & 333 & \\
\hline & & 111 absent & 95 & 174 & 90 & 301 & \\
\hline & & 1111 copy & 5 & 10 & 10 & 32 & $0.4(0.2-1.1), P=0.079$ \\
\hline & & 1112 copies & 0 & 0 & 0 & 0 & \\
\hline & & & & 184 & & 333 & $(163,228)$ \\
\hline MBL2 & Exon 1 & $\mathrm{~g} / \mathrm{g}$ & 63 & 146 & 65 & 169 & \\
\hline (MBL) & $239 \mathrm{G} \rightarrow \mathrm{A}$ & $\mathrm{g} / \mathrm{a}$ & 32 & 73 & 30 & 78 & $1.1(0.7-1.7), P=0.63$ \\
\hline & G57E (C variant) & $\mathrm{a} / \mathrm{a}$ & 5 & 12 & 5 & 14 & $0.9(0.4-2.1), P=0.73$ \\
\hline & & & & 231 & & 261 & $(224,238)$ \\
\hline
\end{tabular}


TABLE 3

Continued

\begin{tabular}{|c|c|c|c|c|c|c|c|}
\hline \multirow[b]{2}{*}{ Gene } & \multirow[b]{2}{*}{ Polymorphism } & \multirow[b]{2}{*}{ Genotype } & \multicolumn{2}{|c|}{ Case } & \multicolumn{2}{|c|}{ Control } & \multirow{2}{*}{$\begin{array}{l}\text { OR } \\
(95 \% \text { confidence interval })\end{array}$} \\
\hline & & & $\%$ & $\mathrm{n}$ & $\%$ & $\mathrm{n}$ & \\
\hline \multirow{16}{*}{$\begin{array}{l}\text { SLC11A1 } \\
\text { (NRAMP1) }\end{array}$} & Promoter microsatellite & 199/199 & 63 & 158 & 56 & 237 & \\
\hline & $(\mathrm{GT}) \mathrm{n}$ & $199 / 201$ & 30 & 75 & 36 & 153 & $0.7(0.5-1.0), P=0.06$ \\
\hline & $(199=$ allele $3,201=$ allele 2$)$ & $201 / 201$ & 4 & 11 & 6 & 25 & $0.6(0.3-1.4), p=0.24$ \\
\hline & & Other & 2 & 5 & 2 & 8 & $1.4(0.4-4.3), P=0.60$ \\
\hline & & & & 249 & & 423 & $(247,388)$ \\
\hline & Exon 2 & Ins/ins & 93 & 228 & 91 & 258 & \\
\hline & 9 bp del & del present & 7 & 16 & 9 & 25 & $0.7(0.3-1.4), P=0.31$ \\
\hline & & & & 244 & & 283 & $(236,261)$ \\
\hline & 3'UTR & Ins/ins & 47 & 122 & 50 & 203 & \\
\hline & TGTG ins/del & Ins/del & 43 & 112 & 41 & 164 & $1.1(0.8-1.5), P=0.64$ \\
\hline & & $\mathrm{del} / \mathrm{del}$ & 9 & 24 & 9 & 35 & $1.2(0.7-2.1), P=0.58$ \\
\hline & & & & 258 & & 402 & $(248,391)$ \\
\hline & $3^{\prime}$ UTR & del/del & 41 & 106 & 45 & 192 & \\
\hline & CAAA ins/del & Ins/del & 45 & 117 & 44 & 191 & $1.1(0.8-1.6), P=0.48$ \\
\hline & & Ins/ins & 14 & 35 & 11 & 46 & $1.5(0.9-2.6), P=0.14$ \\
\hline & & & & 258 & & 429 & $(257,410)$ \\
\hline \multirow[t]{16}{*}{ TLR2 } & Intron 2 microsatellite\# & 216 absent & 90 & 188 & 88 & 332 & \\
\hline & & 2161 copy & 10 & 22 & 12 & 45 & $0.7(0.4-1.3), P=0.25$ \\
\hline & & 2162 copies & 0 & 0 & 0.5 & 2 & \\
\hline & & & & 210 & & 379 & \\
\hline & & 222 absent & 78 & 164 & 79 & 299 & \\
\hline & & 2221 copy & 21 & 44 & 19 & 74 & $0.9(0.6-1.5), P=0.73$ \\
\hline & & 2222 copies & 1 & 2 & 2 & 6 & \\
\hline & & & & 210 & & 379 & \\
\hline & & 224 absent & 37 & 78 & 40 & 151 & \\
\hline & & 2241 copy & 52 & 108 & 50 & 188 & $1.0(0.7-1.4), P=0.91$ \\
\hline & & 2242 copies & 11 & 24 & 10 & 40 & \\
\hline & & & & 210 & & 379 & \\
\hline & & 226 absent & 76 & 160 & 74 & 279 & \\
\hline & & 2261 copy & 21 & 44 & 24 & 92 & $0.9(0.6-1.4), P=0.68$ \\
\hline & & 2262 copies & 3 & 6 & 2 & 8 & \\
\hline & & & & 210 & & 379 & $(194,286)$ \\
\hline \multirow[t]{4}{*}{ TLR4 } & Exon 4 & $\mathrm{a} / \mathrm{a}$ & 95 & 223 & 91 & 262 & \\
\hline & $896 \mathrm{~A} \rightarrow \mathrm{G}$ & $\mathrm{g} / \mathrm{a}$ & 5 & 12 & 9 & 25 & $0.5(0.2-1.1), P=0.08$ \\
\hline & D299G & $\mathrm{g} / \mathrm{g}$ & 0 & 0 & 0.4 & 1 & \\
\hline & & & & 235 & & 288 & $(243,383)$ \\
\hline \multirow[t]{16}{*}{ TNF } & Promoter & $\mathrm{g} / \mathrm{g}$ & 85 & 206 & 84 & 237 & \\
\hline & $-238 \mathrm{G} \rightarrow \mathrm{A}$ & $\mathrm{g} / \mathrm{a}$ & 15 & 36 & 15 & 43 & $0.9(0.5-1.5), P=0.71$ \\
\hline & & $\mathrm{a} / \mathrm{a}$ & 0.4 & 1 & 1 & 3 & $1.4(0.1-16.6), P=0.80$ \\
\hline & & & & 243 & & 283 & $(235,262)$ \\
\hline & Promoter & $\mathrm{g} / \mathrm{g}$ & 80 & 173 & 78 & 201 & \\
\hline & $-308 \mathrm{G} \rightarrow \mathrm{A}$ & $\mathrm{g} / \mathrm{a}$ & 19 & 42 & 20 & 51 & $1.5(0.9-2.5), P=0.15$ \\
\hline & $(\mathrm{TNF} * 1 \rightarrow \mathrm{TNF} * 2)$ & $\mathrm{a} / \mathrm{a}$ & 1 & 1 & 2 & 6 & $0.2(0.02-1.8), P=0.15$ \\
\hline & & & & 216 & & 258 & $(195,223)$ \\
\hline & Promoter & $\mathrm{g} / \mathrm{g}$ & 88 & 211 & 86 & 242 & \\
\hline & $-376 \mathrm{G} \rightarrow \mathrm{A}$ & $\mathrm{g} / \mathrm{a}$ & 11 & 27 & 13 & 38 & $0.8(0.4-1.4), P=0.37$ \\
\hline & & $\mathrm{a} / \mathrm{a}$ & 0.4 & 1 & 1 & 2 & $1.3(0.1-15.8), P=0.83$ \\
\hline & & & & 239 & & 282 & $(231,257)$ \\
\hline & Promoter & $\mathrm{c} / \mathrm{c}$ & 75 & 177 & 75 & 212 & \\
\hline & $-863 \mathrm{C} \rightarrow \mathrm{A}$ & $\mathrm{a} / \mathrm{c}$ & 22 & 51 & 24 & 68 & $0.9(0.6-1.5), P=0.77$ \\
\hline & & $\mathrm{a} / \mathrm{a}$ & 3 & 8 & 1 & 3 & $4.0(0.8-19.7), P=0.09$ \\
\hline & & & & 236 & & 283 & $(228,254)$ \\
\hline \multirow[t]{12}{*}{ VDR } & Intron 8 & $t / t$ & 50 & 85 & 45 & 147 & \\
\hline & $\mathrm{G} \rightarrow \mathrm{T}$ & $\mathrm{t} / \mathrm{g}$ & 43 & 73 & 48 & 158 & $0.7(0.5-1.2), P=0.21$ \\
\hline & $(A p a \mathrm{I} ; \mathrm{a} \rightarrow \mathrm{A})$ & $\mathrm{g} / \mathrm{g}$ & 7 & 11 & 7 & 23 & $1.5(0.6-4.0), P=0.43$ \\
\hline & & & & 169 & & 328 & $(159,235)$ \\
\hline & Intron 8 & $\mathrm{c} / \mathrm{c}$ & 62 & 104 & 60 & 197 & \\
\hline & $\mathrm{C} \rightarrow \mathrm{T}$ & $\mathrm{c} / \mathrm{t}$ & 28 & 47 & 35 & 115 & $0.8(0.5-1.3), P=0.35$ \\
\hline & $(B s m \mathrm{I} ; \mathrm{b} \rightarrow \mathrm{B})$ & $t / t$ & 10 & 17 & 5 & 18 & $2.1(0.9-5.0), P=0.08$ \\
\hline & & & & 168 & & 330 & $(158,235)$ \\
\hline & Exon 9 & $t / t$ & 53 & 131 & 57 & 228 & \\
\hline & $\mathrm{T} \rightarrow \mathrm{C}(\operatorname{codon} 352)$ & $t / c$ & 41 & 101 & 40 & 158 & $1.1(0.8-1.7), P=0.54$ \\
\hline & $(\operatorname{Taq} \mathrm{I} ; \mathrm{T} \rightarrow \mathrm{t})$ & $\mathrm{c} / \mathrm{c}$ & 6 & 15 & 3 & 12 & $4.3(1.6-11.4), P=0.004$ \\
\hline & & & & 247 & & 398 & $(240,375)$ \\
\hline
\end{tabular}

* The results did not change when analysis was restricted to paucibacillary cases and their matched controls.

$\dagger$ For definitions of abbreviations, see Tables 1 and 2.

$\$$ The number of cases and controls used in the logistic regression.

II $P=0.03$, test for heterogeneity among LTA alleles.

\# ORs are for one copy of the allele, and are with respect to baseline of pairs of alleles not including any of 216, 222, 224, and 226. 
leprosy susceptibility; however, for TNF -376 and -238 , the $95 \%$ confidence intervals (CIs) were too wide to eliminate this. The polymorphisms ICAM1 K29M, MBL2 G57E, SLC11A1 exon 2 9-bp deletion, TGTG insertion/deletion, CAAA insertion/deletion, CR1 R1601G, IFNG +874, CCL3 microsatellite, TLR2 intron 2 microsatellite, and IL10 -1082 were not found to be associated with leprosy susceptibility. Borderline evidence of association with leprosy susceptibility was found for six polymorphisms: TNF -863, SLC11A1 promoter microsatellite, IL10 -592, TLR4 D299G, VDR Bsm I, and the LTA microsatellite 111-bp allele. Two SNPs were found to be associated with leprosy susceptibility with a $5 \%$ level of statistical significance without correcting for multiple comparisons: homozygotes (tt) for a silent $\mathrm{T} \rightarrow \mathrm{C}$ change in codon 352 of the VDR gene are susceptible (OR $=4.3,95 \%$ $\mathrm{CI}=1.6-11.4, P=0.004)$, while homozygotes for the CR1 variant $\mathrm{K} 1590 \mathrm{E}$ are protected $(\mathrm{OR}=0.3,95 \% \mathrm{CI}=0.1-0.8$, $P=0.02$ ). Presence of the LTA microsatellite 105-bp allele, but not the overall distribution of alleles at this microsatellite locus, was also associated with leprosy susceptibility $(\mathrm{OR}=$ $1.6,95 \% \mathrm{CI}=1.1-2.4, P=0.03)$.

Association study results for leprosy type. Comparison of genotype frequency between $\mathrm{MB}$ and $\mathrm{PB}$ cases usually indicated no differences. However, there was suggestive evidence that presence of the LTA 101-bp microsatellite allele is associated with MB leprosy $\left(\chi^{2}=11.4, P=0.003\right)$ and borderline evidence that the TLR2 224-bp microsatellite allele $\left(\chi^{2}=6.3\right.$, $P=0.042)$ genotype frequencies may differ between leprosy types. However, since only $26 \mathrm{MB}$ cases were included in this study these results could be due to sampling error.

\section{DISCUSSION}

Of the 38 polymorphisms investigated, 12 were insufficiently polymorphic for analysis and 2 showed evidence of association with leprosy susceptibility in this population. These two are discussed first.

The nuclear hormone receptor VDR mediates the many immunomodulatory effects of the active form of vitamin $\mathrm{D}$ $\left(1 \alpha 25(\mathrm{OH})_{2} \mathrm{D} 3\right)$, which include suppression of cytokine synthesis, immunoglobulin production, and lymphocyte proliferation. Epidemiologic evidence suggests that vitamin D deficiency may be associated with susceptibility to tuberculosis and vitamin D impairs growth of M. tuberculosis in human macrophage and monocytic cell lines, while vitamin Dcontaining medications have been useful in treating some leprosy cases. ${ }^{10,24}$ Homozygosity for a Taq I polymorphism (tt) in the ligand binding domain of VDR was associated with PB leprosy in Bengali Indians and resistance to tuberculosis in The Gambia. ${ }^{10,25}$ In the Bengali leprosy study the TT genotype was associated with MB leprosy and the Tt genotype was associated with leprosy susceptibility per se. In Karonga, where the leprosy cases are predominantly $(90 \%) \mathrm{PB}$, the $\mathrm{tt}$ genotype was associated with susceptibility to leprosy per se. However, the apparent association in Karonga should be interpreted with caution. The expected frequency of tt homozygotes based on the measured $\mathrm{t}$ allele frequency in controls is $5 \%$. The observed frequency in cases is $6 \%$ and in controls $3 \%$. Thus, much of the apparent difference relates to a deviation of the control frequency from Hardy-Weinberg equilibrium, which may be a chance finding. In Mali, no associa- tion was found for the VDR genotype with either lepromatous or tuberculoid leprosy or leprosy per se (Meisner S, unpublished data). It is not clear whether the silent $\mathrm{T} / \mathrm{t}$ polymorphism has a direct effect on function or expression of VDR, and it seems more likely that reported disease associations, if real, relate to linkage disequilibrium with a flanking functional polymorphism. ${ }^{26,27}$

On phagocytic cells, CR1 mediates the adherence and phagocytosis of complement-opsonized pathogens. Since $M$. leprae and $M$. tuberculosis can both gain entry into macrophages using this mechanism, it was hypothesized that variants in CR1 may influence susceptibility to mycobacterial disease. $^{28,29}$ Five polymorphisms that encode amino acid changes in the extracellular domains of the protein and may affect either ligand binding or CR1 stability were investigated. ${ }^{30,31}$ These included the variants K1590E and R1601G, which underlie the Knops blood group McCoy $\left(M c C^{a} \rightarrow M c C^{b}\right)$ and Swain-Langley $(S l 1 \rightarrow S l 2)$ polymorphisms, respectively. Both the $M c C^{b}$ and $S l 2$ alleles are more prevalent in African populations than in Caucasian, Asian, or Hispanic Americans, and it has been suggested that they may confer a selective advantage against infectious disease. ${ }^{32}$ These alleles were less common in Malawi $\left(M c C^{b}=0.23, S l 2\right.$ $=0.31)$ than in the west African Gambian population $\left(M c C^{b}\right.$ $=0.39, S l 2=0.80)$, but more common than in non-African populations $\left(M c C^{b} \leq 0.025, S l 2 \leq 0.03\right)$. Homozygosity for the $M c C^{b}$ allele was associated with protection against leprosy in Malawi; however, the biologic mechanism underlying this finding is unclear.

Four other genes, TNF, LTA, IL-10, and TLR2, which have been reported to be associated with leprosy susceptibility elsewhere, failed to show association of the relevant polymorphisms in Karonga. ${ }^{3}$

The proinflammatory cytokine TNF influences several aspects of the immune response, including macrophage activation (important for killing of mycobacteria) and granuloma formation (important for containment of mycobacterial infections), and can also cause tissue damage and apoptosis. Several promoter polymorphisms exist which may be involved in regulation of TNF expression and such variants have been associated with both autoimmune and infectious diseases. ${ }^{33-35} \mathrm{~A} \mathrm{G} \rightarrow \mathrm{A}$ polymorphism $\left(\mathrm{TNF}^{* 2}\right.$ ) at -308 , which may be associated with increased TNF expression, was strongly linked to and associated with resistance to leprosy in Brazil. 6,9,36,37 Contrary to these findings, the same variant has been associated with MB leprosy susceptibility in Bengali Indians, indicating, perhaps, that different aspects of TNF may be important in controlling the outcome of leprosy infection in different populations, perhaps due to the presence of different $M$. leprae strains, or a modified cytokine milieu resulting from presence of varying infectious pathogens or differences in genetic backgrounds. ${ }^{38}$ We found no evidence that the -308 variant has a role in leprosy susceptibility in Malawi. Six other TNF polymorphisms were investigated in this study, but the $-1031,+70$ and -857 variants were very rare and thus could not be tested for any association. There was no evidence that the -376 polymorphism, which upregulates TNF expression by introducing a binding site for the OCT-1 transcription factor, and is associated with severe malaria, was associated with leprosy susceptibility in Malawi, although the confidence limits were too wide to eliminate this possibility. ${ }^{33}$ Consistent with a recent Brazilian leprosy study, the -238 
SNP, which may produce increased TNF transcription, was not found to be associated with leprosy in Malawi. ${ }^{9,39}$ The $-863 \mathrm{SNP}$ is located in an NF- $\mathrm{B}$ regulatory site and results in reduced p50-p50 enhancement of expression. ${ }^{40}$ There was borderline evidence that this variant may be associated with leprosy susceptibility in Malawi, which is consistent with the findings that higher levels of TNF production may be protective against leprosy in Brazil.

Located close to the TNF gene, LTA encodes a cytokine that is produced by lymphocytes and natural killer cells and which has pleiotropic immunomodulatory effects. A haplotype that includes an intronic LTA SNP is associated with leprosy susceptibility in Brazil. ${ }^{6}$ In Malawi, the 105-bp allele may be weakly associated with leprosy susceptibility, while the 101-bp allele may influence leprosy type. It is possible that these associations are due to linkage disequilibrium with other polymorphisms either in another gene in the HLA region, or within LTA, or they may just be chance findings. ${ }^{20}$ However, further investigation of possible associations, if any, between LTA and susceptibility both to leprosy per se, and to leprosy type is warranted.

The cytokine IL10 has pleiotropic effects in immunoregulation and inflammation, including the inhibition of TH1 cytokine secretion and $\mathrm{T}$ cell proliferation. Polymorphisms in the promoter influence the amount of IL10 production. ${ }^{10,41,42}$ It was speculated that by suppressing inflammation, high IL10 production might increase mycobacterial susceptibility. Three promoter polymorphisms in IL10 were investigated in Malawi and borderline evidence was found that homozygotes for the -592 A variant may have increased susceptibility to leprosy. Recently, the $-819 \mathrm{~T}$ variant has been reported to be weakly associated with leprosy susceptibility in Brazil. ${ }^{9}$ These two variants exhibit linkage disequilibrium and usually occur together on a haplotype $(-1082 \mathrm{~A},-1892 \mathrm{~T},-592 \mathrm{~A})$ that is associated with increased IL10 production. In Brazil, homozygosity for the -592 A variant is not significantly associated with susceptibility, but there is a trend in this direction. Thus, it is possible that the ATA haplotype may be associated with leprosy susceptibility in both these populations but much larger studies would be required to assess this.

Mammalian toll-like receptors recognize and react to a variety of bacterial cell wall components to activate direct antimicrobial mechanisms and to facilitate transcription of genes that regulate the adaptive inflammatory immune response. TLR2, probably acting as a heterodimer with other TLRs, recognizes components from a variety of microbial pathogens including mycobacterial lipoproteins and lipoarabinomannan. Mycobacterium leprae can activate both TLR2TLR1 heterodimers and TLR2 homodimers. ${ }^{43}$ TLR4 is the receptor for lipopolysaccharide (LPS), a major cell wall component of gram-negative bacteria, but it seems that both TLR2 and TLR4 can mediate cellular activation in response to components of gram-positive Mycobacterium tuberculosis. ${ }^{44}$ An Arg299Gly polymorphism in the extracellular domain results in impaired TLR4-mediated LPS induced signaling. ${ }^{45}$ Heterozygosity is associated with hypo-responsiveness to inhaled LPS, Thus, it appears counter-intuitive that although only borderline significant, heterozygosity for the rare 299Gly allele was increased among controls. ${ }^{46}$ It would be of interest to determine whether this genotype is associated with protection in other populations.

Three TLR2 polymorphisms were also investigated. Se- quencing indicated that Arg677Trp and Arg753Gln, identified as rare variants in other populations, are extremely rare in Malawi and variation in a microsatellite located in intron 2 of the TLR2 gene was not associated with leprosy susceptibility. ${ }^{13,22}$

Mannose-binding lectin binds to mannose and $\mathrm{N}$ acetylglucosamine groups on a variety of bacteria, resulting in complement activation and opsonophagocytosis. Any one of three exon 1 point mutations (R52C, G54D, and G57E) reduces serum MBL concentrations. Since low serum levels of MBL may be associated with recurrent infections in young children and yet low-producing alleles are maintained in all populations, as for ICAM1, it has been proposed that balancing selection might exist. ${ }^{47}$ One hypothesis is that low MBL levels may protect against mycobacterial disease by limiting phagocytotic entry of mycobacteria into host cells. ${ }^{48}$ Consistent with studies of other African populations, the R52C and G54D polymorphisms were found only rarely in Malawi. The G57E (C) variant had an allele frequency of $20 \%$ and was not associated with leprosy susceptibility.

Interferon- $\gamma$ is an essential and central regulator of the human response to infection. The intronic +874 T/A SNP lies in a putative binding site for the transcription factor NF-кB. The $\mathrm{T}$ allele, which may be associated with high IFN- $\gamma$ production has recently been found to be associated with resistance to tuberculosis in Sicilians and South Africans. ${ }^{10,19,49,50}$ This SNP has not previously been investigated for an association with leprosy susceptibility and was not found to be associated with leprosy in Malawi. This could be because the lower allele frequency in Malawi (20\% compared with 50\%) reduces the power to detect such an association because the tuberculosis association is due to another polymorphism that is in linkage disequilibrium with the +874 SNP in Sicily but not in Malawi, or because this allele does not affect leprosy susceptibility in this population.

The SLC11A1 gene encodes a protein that may have a direct effect on the survival of mycobacteria within macrophage phagosomes, but may also have pleiotropic effects that include regulation of the TH1:TH2 balance of the adaptive immune response to infection. Since the mouse homolog Slc11a1 protects against some mycobacterial infections and SLC11A1 variants have been associated with human tuberculosis susceptibility, SLC11A1 has long been a candidate for leprosy susceptibility. However, although a haplotype segregation study suggested this gene may influence leprosy susceptibility in Vietnam, ${ }^{51}$ other studies have found no evidence for association and/or linkage with susceptibility. ${ }^{25,51-54}$ However, variants of this gene have been associated with leprosy type in Mali and linked with the size of the Mitsuda response in southeast Asians. ${ }^{53,55}$ For three of the four SLC11A1 polymorphisms examined in the Malawi population, there was no evidence of an association with leprosy susceptibility. The fourth, a promoter microsatellite, showed borderline evidence that the putative lower-expressing allele 201 (allele 2) may be protective against leprosy in this population. This contrasts with the reported association of this allele with tuberculosis susceptibility in The Gambia. ${ }^{10,56}$

The aim of this study was to better understand the genetic factors that underlie host immune responses to leprosy. We find evidence that variants in the VDR and CR1 genes may influence leprosy susceptibility in the Karonga District of northern Malawi, and it is possible that variants of some of 
the others genes studied may also play a minor role. The sibling risk ratio for leprosy in this population appears to be of the order of two, and thus the genes and modest associations studied here appear insufficient to account for the overall genetic component identified. ${ }^{57}$ Therefore, it seems likely that there are several other host genes that contribute to a complex network of gene products that may synergize or counteract each other to influence leprosy susceptibility. Interaction of strain, environment, nutrition, presence and nature of concurrent background infections, varying linkage disequilibrium, and allele frequencies may limit the usefulness of extrapolating these findings to other populations. Indeed, a major conclusion from this large-scale study is that many of the associations suggested by studies in other populations are not found in this Malawian population. Our data urge caution in the interpretation of infectious disease genetic associations from single-population analyses and support the reassessment of positive findings in replication studies.

Received August 28, 2003. Accepted for publication January 19, 2004.

Acknowledgments: We thank the many field, laboratory, and data management staff of the KPS who have carried out the leprosy work in Karonga District since 1979, the people of Karonga District, and the Ministry of Health and Population and the National Health Sciences Research Committee of Malawi for their encouragement of the KPS over many years. We also thank past and present Wellcome Trust Centre for Human Genetics (WTCHG) researchers and collaborators including Peter Zimmerman, Patricia Ramaley, and Graham Cooke for their role in developing the genotyping methods used here, as well as WTCHG core facilities staff, and Kerrie Tosh, Christophe Aucan, and Dr. Branwen Hennig, for their assistance.

Financial support: The leprosy work of the KPS has been funded since its inception by the British Leprosy Relief Association, with contributions from the International Federation of Anti-Leprosy Associations. This study was supported by the Wellcome Trust. Adrian V. S. Hill is a Wellcome Trust Principal Research Fellow.

Authors' addresses: Jodene Fitness, School of Biological Sciences, Victoria University of Wellington, PO Box 600, Wellington, New Zealand, E-mail: jodene.fitness@vuw.ac.nz. Sian Floyd and Paul E. M. Fine, Department of Tropical Hygiene, London School of Hygiene and Tropical Medicine, Keppel Street, London WC1E 7HT, United Kingdom, E-mails: sian.floyd@1shtm.ac.uk and paul.fine@lshtm.ac.uk. David K. Warndorff, Lifted Sichali, Lorren Mwaungulu, and Amelia C. Crampin, Karonga Prevention Study, PO Box 46, Chilumba, Karonga District, Malawi. Adrian V. S. Hill, Wellcome Trust Centre for Human Genetics, Roosevelt Drive, Oxford OX3 7BN, United Kingdom, E-mail: adrian.hill@molecularmedicine.oxford.ac.uk.

\section{REFERENCES}

1. Fine PE, 1988. Implications of genetics for the epidemiology and control of leprosy. Philos Trans R Soc Lond B Biol Sci 321: 365-376.

2. Chakravartti MR, Vogel F, 1973. A twin study on leprosy. Top Hum Genet 1: 1-123.

3. Fitness J, Tosh K, Hill AV, 2002. Genetics of susceptibility to leprosy. Genes Immun 3: 441-453.

4. Tosh K, Meisner S, Siddiqui MR, Balakrishnan K, Ghei S, Golding M, Sengupta U, Pitchappan RM, Hill AV, 2002. A region of chromosome 20 is linked to leprosy susceptibility in a south Indian population. J Infect Dis 186: 1190-1193.

5. Todd JR, West BC, McDonald JC, 1990. Human leukocyte antigen and leprosy: study in northern Louisiana and review. Rev Infect Dis 12: 63-74.

6. Shaw MA, Donaldson IJ, Collins A, Peacock CS, Lins-Lainson Z, Shaw JJ, Ramos F, Silveira F, Blackwell JM, 2001. Association and linkage of leprosy phenotypes with HLA class II and tumour necrosis factor genes. Genes Immun 2: 196-204.

7. Siddiqui MR, Meisner S, Tosh K, Balakrishnan K, Ghei S, Fisher SE, Golding M, Shanker Narayan NP, Sitaraman T, Sengupta U, Pitchappan R, Hill AV, 2001. A major susceptibility locus for leprosy in India maps to chromosome 10p13. Nat Genet 27: 439-441.

8. Mira MT, Alcais A, van Thuc N, Thai VH, Huong NT, Ba NN, Verner A, Hudson TJ, Abel L, Schurr E, 2003. Chromosome $6 \mathrm{q} 25$ is linked to susceptibility to leprosy in a Vietnamese population. Nat Genet 33: 412-415.

9. Santos AR, Suffys PN, Vanderborght PR, Moraes MO, Vieira LM, Cabello PH, Bakker AM, Matos HJ, Huizinga TW, Ottenhoff TH, Sampaio EP, Sarno EN, 2002. Role of tumor necrosis factor-alpha and interleukin-10 promoter gene polymorphisms in leprosy. J Infect Dis 186: 1687-1691.

10. Fitness J, Floyd S, Warndorff DK, Sichali L, Malema S, Crampin AC, Fine PEM, Hill AVS, 2004. Large-scale candidate gene study of tuberculosis susceptibility in the Karonga district of northern Malawi. Am J Trop Med Hyg 70: (in press).

11. Fernandez-Reyes D, Craig AG, Kyes SA, Peshu N, Snow RW, Berendt AR, Marsh K, Newbold CI, 1997. A high frequency African coding polymorphism in the N-terminal domain of ICAM-1 predisposing to cerebral malaria in Kenya. Hum Mol Genet 6: 1357-1360.

12. Shin HD, Winkler C, Stephens JC, Bream J, Young H, Goedert JJ, O'Brien TR, Vlahov D, Buchbinder S, Giorgi J, Rinaldo C, Donfield S, Willoughby A, O'Brien SJ, Smith MW, 2000. Genetic restriction of HIV-1 pathogenesis to AIDS by promoter alleles of IL10. Proc Natl Acad Sci U S A 97: 14467-14472.

13. Lorenz E, Mira JP, Cornish KL, Arbour NC, Schwartz DA, 2000. A novel polymorphism in the toll-like receptor 2 gene and its potential association with staphylococcal infection. Infect Immun 68: 6398-6401.

14. Ponnighaus JM, Fine PE, Sterne JA, Bliss L, Wilson RJ, Malema SS, Kileta S, 1994. Incidence rates of leprosy in Karonga District, northern Malawi: patterns by age, sex, BCG status and classification. Int J Lepr Other Mycobact Dis 62: 10-23.

15. Ponninghaus JM, Fine PE, Bliss L, Sliney IJ, Bradley DJ, Rees RJ, 1987. The Lepra Evaluation Project (LEP), an epidemiological study of leprosy in northern Malawi. I. Methods. Lepr Rev 58: 359-375.

16. Ponnighaus JM, Fine PE, Bliss L, 1987. Certainty levels in the diagnosis of leprosy. Int J Lepr Other Mycobact Dis 55: 454462.

17. Ponnighaus JM, Mwanjasi LJ, Fine PE, Shaw MA, Turner AC, Oxborrow SM, Lucas SB, Jenkins PA, Sterne JA, Bliss L, 1991. Is HIV infection a risk factor for leprosy? Int J Lepr Other Mycobact Dis 59: 221-228.

18. van Heel DA, McGovern DP, Cardon LR, Dechairo BM, Lench NJ, Carey AH, Jewell DP, 2002. Fine mapping of the IBD1 locus did not identify Crohn disease-associated NOD2 variants: implications for complex disease genetics. Am J Med Genet 111: 253-259.

19. Pravica V, Perrey C, Stevens A, Lee JH, Hutchinson IV, 2000. A single nucleotide polymorphism in the first intron of the human IFN-gamma gene: absolute correlation with a polymorphic CA microsatellite marker of high IFN-gamma production. Hum Immunol 61: 863-866.

20. Jongeneel CV, Briant L, Udalova IA, Sevin A, Nedospasov SA Cambon-Thomsen A, 1991. Extensive genetic polymorphism in the human tumor necrosis factor region and relation to extended HLA haplotypes. Proc Natl Acad Sci U S A 88: 97179721.

21. Al-Sharif FM, Makki RF, Ollier WE, Hajeer AH, 1999. A new microsatellite marker within the promoter region of the MIP1A gene. Immunogenetics 49: 740-741.

22. Kang TJ, Chae GT, 2001. Detection of Toll-like receptor 2 (TLR2) mutation in the lepromatous leprosy patients. FEMS Immunol Med Microbiol 31: 53-58.

23. Day DJ, Speiser PW, White PC, Barany F, 1995. Detection of steroid 21-hydroxylase alleles using gene-specific PCR and a multiplexed ligation detection reaction. Genomics 29: 152-162.

24. Rogers L, 1921. Chaulmoogra oil in leprosy and tuberculosis. Lancet 1: 1178-1180. 
25. Roy S, Frodsham A, Saha B, Hazra SK, Mascie-Taylor CG, Hill AV, 1999. Association of vitamin D receptor genotype with leprosy type. J Infect Dis 179: 187-191.

26. Verbeek W, Gombart AF, Shiohara M, Campbell M, Koeffler HP, 1997. Vitamin D receptor: no evidence for allele-specific mRNA stability in cells which are heterozygous for the Taq I restriction enzyme polymorphism. Biochem Biophys Res Commun 238: 77-80.

27. Mocharla H, Butch AW, Pappas AA, Flick JT, Weinstein RS, De Togni P, Jilka RL, Roberson PK, Parfitt AM, Manolagas SC, 1997. Quantification of vitamin D receptor mRNA by competitive polymerase chain reaction in PBMC: lack of correspondence with common allelic variants. J Bone Miner Res 12: 726-733.

28. Schlesinger LS, Horwitz MA, 1990. Phagocytosis of leprosy bacilli is mediated by complement receptors CR1 and CR3 on human monocytes and complement component $\mathrm{C} 3$ in serum. $J$ Clin Invest 85: 1304-1314.

29. Hirsch CS, Ellner JJ, Russell DG, Rich EA, 1994. Complement receptor-mediated uptake and tumor necrosis factor-alphamediated growth inhibition of Mycobacterium tuberculosis by human alveolar macrophages. J Immunol 152: 743-753.

30. Moulds JM, Zimmerman PA, Doumbo OK, Kassambara L, Sagara I, Diallo DA, Atkinson JP, Krych-Goldberg M, Hauhart RE, Hourcade DE, McNamara DT, Birmingham DJ, Rowe JA, Moulds JJ, Miller LH, 2001. Molecular identification of Knops blood group polymorphisms found in long homologous region D of complement receptor 1. Blood 97: 2879-2885.

31. Xiang L, Rundles JR, Hamilton DR, Wilson JG, 1999. Quantitative alleles of CR1: coding sequence analysis and comparison of haplotypes in two ethnic groups. J Immunol 163: 4939-4945.

32. Zimmerman PA, Fitness J, Moulds JM, McNamara DT, Kasehagen LJ, Rowe JA, Hill AV, 2003. CR1 Knops blood group alleles are not associated with severe malaria in the Gambia. Genes Immun 4: 368-373.

33. Knight JC, Udalova I, Hill AV, Greenwood BM, Peshu N, Marsh K, Kwiatkowski D, 1999. A polymorphism that affects OCT-1 binding to the TNF promoter region is associated with severe malaria. Nat Genet 22: 145-150.

34. Cabrera M, Shaw MA, Sharples C, Williams H, Castes M, Convit J, Blackwell JM, 1995. Polymorphism in tumor necrosis factor genes associated with mucocutaneous leishmaniasis. $J$ Exp Med 182: $1259-1264$.

35. Sashio H, Tamura K, Ito R, Yamamoto Y, Bamba H, Kosaka T, Fukui S, Sawada K, Fukuda Y, Satomi M, Shimoyama T, Furuyama J, 2002. Polymorphisms of the TNF gene and the TNF receptor superfamily member $1 \mathrm{~B}$ gene are associated with susceptibility to ulcerative colitis and Crohn's disease, respectively. Immunogenetics 53: 1020-1027.

36. Santos AR, Almeida AS, Suffys PN, Moraes MO, Filho VF, Mattos HJ, Nery JA, Cabello PH, Sampaio EP, Sarno EN, 2000. Tumor necrosis factor promoter polymorphism (TNF2) seems to protect against development of severe forms of leprosy in a pilot study in Brazilian patients. Int J Lepr Other Mycobact Dis 68: $325-327$.

37. Moraes MO, Duppre NC, Suffys PN, Santos AR, Almeida AS, Nery JA, Sampaio EP, Sarno EN, 2001. Tumor necrosis factoralpha promoter polymorphism TNF2 is associated with a stronger delayed-type hypersensitivity reaction in the skin of borderline tuberculoid leprosy patients. Immunogenetics 53: 45-47.

38. Roy S, McGuire W, Mascie-Taylor CG, Saha B, Hazra SK, Hill AV, Kwiatkowski D, 1997. Tumor necrosis factor promoter polymorphism and susceptibility to lepromatous leprosy. $J$ Infect Dis 176: 530-532.

39. Bayley JP, de Rooij H, van den Elsen PJ, Huizinga TW, Verweij CL, 2001. Functional analysis of linker-scan mutants spanning the $-376,-308,-244$, and -238 polymorphic sites of the TNFalpha promoter. Cytokine 14: 316-323.

40. Udalova IA, Richardson A, Denys A, Smith C, Ackerman H, Foxwell B, Kwiatkowski D, 2000. Functional consequences of a polymorphism affecting NF-kappaB p50-p50 binding to the TNF promoter region. Mol Cell Biol 20: 9113-9119.
41. Gibson AW, Edberg JC, Wu J, Westendorp RG, Huizinga TW, Kimberly RP, 2001. Novel single nucleotide polymorphisms in the distal IL-10 promoter affect IL-10 production and enhance the risk of systemic lupus erythematosus. J Immunol 166 : 3915-3922.

42. Rees LE, Wood NA, Gillespie KM, Lai KN, Gaston K, Mathieson PW, 2002. The interleukin-10-1082 G/A polymorphism: allele frequency in different populations and functional significance. Cell Mol Life Sci 59: 560-569.

43. Krutzik SR, Ochoa MT, Sieling PA, Uematsu S, Ng YW, Legaspi A, Liu PT, Cole ST, Godowski PJ, Maeda Y, Sarno EN, Norgard MV, Brennan PJ, Akira S, Rea TH, Modlin RL, 2003. Activation and regulation of Toll-like receptors 2 and 1 in human leprosy. Nat Med 9: 525-532.

44. Means TK, Wang S, Lien E, Yoshimura A, Golenbock DT, Fenton MJ, 1999. Human toll-like receptors mediate cellular activation by Mycobacterium tuberculosis. J Immunol 163: 39203927.

45. Arbour NC, Lorenz E, Schutte BC, Zabner J, Kline JN, Jones M, Frees K, Watt JL, Schwartz DA, 2000. TLR4 mutations are associated with endotoxin hyporesponsiveness in humans. Nat Genet 25: 187-191.

46. Lorenz E, Mira JP, Frees KL, Schwartz DA, 2002. Relevance of mutations in the TLR4 receptor in patients with gram-negative septic shock. Arch Intern Med 162: 1028-1032.

47. Garred P, Madsen HO, Kurtzhals JA, Lamm LU, Thiel S, Hey AS, Svejgaard A, 1992. Diallelic polymorphism may explain variations of the blood concentration of mannan-binding protein in Eskimos, but not in black Africans. Eur J Immunogenet 19: 403-412.

48. Garred P, Harboe M, Oettinger T, Koch C, Svejgaard A, 1994. Dual role of mannan-binding protein in infections: another case of heterosis? Eur J Immunogenet 21: 125-131.

49. Lio D, Marino V, Serauto A, Gioia V, Scola L, Crivello A, Forte GI, Colonna-Romano G, Candore G, Caruso C, 2002. Genotype frequencies of the $+874 \mathrm{~T} \rightarrow \mathrm{A}$ single nucleotide polymorphism in the first intron of the interferon-gamma gene in a sample of Sicilian patients affected by tuberculosis. Eur J Immunogenet 29: 371-374.

50. Rossouw M, Nel HJ, Cooke GS, van Helden PD, Hoal EG, 2003. Association between tuberculosis and a polymorphic NFkappaB binding site in the interferon gamma gene. Lancet 361: 1871-1872.

51. Abel L, Sanchez FO, Oberti J, Thuc NV, Hoa LV, Lap VD, Skamene E, Lagrange PH, Schurr E, 1998. Susceptibility to leprosy is linked to the human NRAMP1 gene. J Infect Dis 177: 133-145.

52. Shaw MA, Atkinson S, Dockrell H, Hussain R, Lins-Lainson Z, Shaw J, Ramos F, Silveira F, Mehdi SQ, Kaukab F, 1993. An RFLP map for 2q33-q37 from multicase mycobacterial and leishmanial disease families: no evidence for an Lsh/Ity/Bcg gene homologue influencing susceptibility to leprosy. Ann Hum Genet 57: 251-271.

53. Meisner SJ, Mucklow S, Warner G, Sow SO, Lienhardt C, Hill AV, 2001. Association of NRAMP1 polymorphism with leprosy type but not susceptibility to leprosy per se in west Africans. Am J Trop Med Hyg 65: 733-735.

54. Medina E, Rogerson BJ, North RJ, 1996. The Nramp1 antimicrobial resistance gene segregates independently of resistance to virulent Mycobacterium tuberculosis. Immunology 88: 479481.

55. Alcais A, Sanchez FO, Thuc NV, Lap VD, Oberti J, Lagrange PH, Schurr E, Abel L, 2000. Granulomatous reaction to intradermal injection of lepromin (Mitsuda reaction) is linked to the human NRAMP1 gene in Vietnamese leprosy sibships. $J$ Infect Dis 181: 302-308.

56. Bellamy R, Ruwende C, Corrah T, McAdam KP, Whittle HC, Hill AV, 1998. Variations in the NRAMP1 gene and susceptibility to tuberculosis in west Africans. $N$ Engl J Med 338: 640-644.

57. Wallace C, Clayton D, Fine P, 2003. Estimating the relative recurrence risk ratio for leprosy in Karonga District, Malawi. Lepr Rev 74: 133-140. 